\title{
Communication
}

[Comunicação]

\section{Nutritional composition of larvae of mealworm (Tenebrio molitor L.) and crickets (Gryllus assimilis) with potential usage in feed}

\author{
[Composição nutricional de larvas de Tenebrio molitor e de grilos (Gryllus assimilis) com \\ potencial de uso na alimentação animal]
}

\author{
A.T.S. Fialho ${ }^{1}$, A.S. Silva ${ }^{1}$, C.O. Brito ${ }^{3}$, P.A.C.B. Vale $^{2}$, \\ C.J.P. Oliveira ${ }^{2}$, V. Ribeiro Junior ${ }^{2 *}$
}

\begin{abstract}
${ }^{1}$ Aluno de graduação - Universidade Federal de Sergipe - Campus do Sertão - Nossa Senhora da Glória, SE ${ }^{2}$ Universidade Federal de Sergipe - Núcleo de Zootecnia - Campus do Sertão - Nossa Senhora da Glória, SE ${ }^{3}$ Universidade Federal de Sergipe -São Cristóvão, SE
\end{abstract}

The use of insects in animal feed currently presents itself as an alternative to soybean meal since it requires low land and water for its production. The Tenebrio molitor is reported as an easy breeding and maintenance insect due to the low production cost. In addition, these insects have been evaluated both in human food (Costa, 2017) and animal feed (Belforti et al., 2015). Another interesting species is the cricket of the genus Gryllus assimilis, since it has a high rate of reproduction and development at certain time of the year, mainly due to heat, humidity, and the presence of crops such as corn and soybean. Semi-arid Regions, such as the Northeast of Brazil, present low soy production and may, eventually, present a shortage of protein sources for use in animal feed.

Thus, the use of insects can be an alternative to solve this problem. However, there is little information about the chemical composition of different types of insects. In addition, the nutritional composition of insects can be changed depending on their diet (Siemianowska et al., 2013). The aim of the present study was to determine the nutritional composition of Tenebrio molitor larvae and crickets of the genus Gryllus assimilis for usage in animal feed.

\section{MATERIAL AND METHODS}

The study was approved by the Ethics Committee in Research with Production Animals

Recebido em 25 de agosto de 2020 Aceito em 14 de dezembro de 2020

*Autor para correspondência

E-mail: valribjunior@academico.ufs.br
(CEPAP) of the Federal University of Sergipe, under protocol number 03/2019. Chemical analyses of insects followed the protocols described by AOAC (Official..., 1990). Samples of Tenebrio larvae and crickets were placed in plastic containers, weighed, and euthanized in a freezer at $-6^{\circ} \mathrm{C}$. Then, the samples were dried in forced circulation ovens at $55^{\circ} \mathrm{C}$ and ground in a ball mill. The dry matter content of the samples was determined according to protocol 934.01. The crude protein (CP) content was determined by the Kjeldahl method (protocol 954.01). The gross energy (GE) was determined using a calorimetric combustion pump (IKAC200).

The content of ether extract (EE) was determined using the Soxhlet method (protocol 955.04). The ash content (Ash) was determined according to the 942.05 protocol. The levels of neutral detergent fiber (NDF) and acid detergent fiber (ADF) were determined according to protocol 937.18. The content of phosphorus (P) was determined by a colorimetric test (Fiske and Subbarow, 1925). Acid molybdate and reducing solution were added to wet-ash samples to make a phosphorus-molybdenum complex. The color intensity was proportional to the $\mathrm{P}$ concentration and was determined with a spectrophotometer using absorbance at $620 \mathrm{~nm}$ (SpectraCount, Model \# AS1000, Packard, Meridian, CT). The other macrominerals and trace minerals were obtained from dry digestion.

Potassium (K) was determined by the method of flame photometry, while sodium $(\mathrm{Na})$, calcium $(\mathrm{Ca})$, magnesium $(\mathrm{Mg})$, iron $(\mathrm{Fe})$, manganese 
$(\mathrm{Mn})$, zinc $(\mathrm{Zn})$ and copper $(\mathrm{Cu})$ were determined by the atomic absorption spectrophotometric method (protocol 968.08) using an atomic absorption spectrometer (AAnalyst 300, Perkin Elmer, Norwalk, CT).

\section{RESULTS AND DISCUSSION}

Proximal composition and mineral content of Tenebrio molitor larvae and crickets of the genus Gryllus assimilis are shown in Table 1.

Table 1. Proximal composition and mineral content of Tenebrio molitor larvae and crickets of the genus Gryllus assimilis (dry matter-basis)

\begin{tabular}{|c|c|c|}
\hline \multirow[b]{2}{*}{ Item $^{1}$} & \multicolumn{2}{|c|}{ Values } \\
\hline & Tenebrio molitor larvae & $\begin{array}{c}\text { Crickets } \\
\text { (Gryllus assimilis) }\end{array}$ \\
\hline Crude Protein, $\mathrm{g} / \mathrm{kg}$ & 490.2 & 541.3 \\
\hline Ether extract, $\mathrm{g} / \mathrm{kg}$ & 335.4 & 75.2 \\
\hline Gross Energy, kcal/kg & $7,188.6$ & $5,942.6$ \\
\hline $\mathrm{NDF}, \mathrm{g} / \mathrm{kg}$ & 71.8 & 277.8 \\
\hline $\mathrm{ADF}, \mathrm{g} / \mathrm{kg}$ & 64.0 & 193.0 \\
\hline Ash, $\mathrm{g} / \mathrm{kg}$ & 36.8 & 49.1 \\
\hline \multicolumn{3}{|l|}{ Macrominerals } \\
\hline Total phosphorus, $\mathrm{g} / \mathrm{kg}$ & 8.56 & 8.3 \\
\hline Potassium, $\mathrm{g} / \mathrm{kg}$ & 8.39 & 11.6 \\
\hline Sodium, $\mathrm{g} / \mathrm{kg}$ & 1.39 & 1.10 \\
\hline Total calcium, $\mathrm{g} / \mathrm{kg}$ & 0.44 & 3.88 \\
\hline Magnesium, g/kg & 2.30 & 0.82 \\
\hline \multicolumn{3}{|l|}{ Trace minerals } \\
\hline Iron, $\mathrm{mg} / \mathrm{kg}$ & 48.4 & 96.8 \\
\hline Manganese, $\mathrm{mg} / \mathrm{kg}$ & 15.0 & 23.7 \\
\hline Zinc, $\mathrm{mg} / \mathrm{kg}$ & 189 & 18.3 \\
\hline Copper, $\mathrm{mg} / \mathrm{kg}$ & 18.0 & 21.7 \\
\hline
\end{tabular}

${ }^{1}$ Chemical analyses followed the protocols described in AOAC (Official..., 1990).

The CP content in Tenebrio molitor larvae was $490.2 \mathrm{~g} / \mathrm{kg}$. Past studies reported similar results (Costa, 2017; Fontes et al., 2019). The observed $\mathrm{CP}$ in crickets was $541.3 \mathrm{~g} / \mathrm{kg}$. In addition to the high content of $\mathrm{CP}$, insects have high digestibility since they are products from animal origin (De Marco et al., 2015).

Larvae of mealworm (Tenebrio molitor L.) and crickets showed EE contents of $335.4 \mathrm{~g} / \mathrm{kg}$ and $75.2 \mathrm{~g} / \mathrm{kg}$, respectively. Barroso et al. (2014) observed EE content in larvae of mealworm varying from 294.0 to $308.0 \mathrm{~g} / \mathrm{kg}$. The edible insects have been stated to have more nutritional contents than other conventional food, such as soybean and meat (Ravzanaadii et al., 2012). Siemianowska et al. (2013) reported larvae of mealworm (Tenebrio molitor L.) contains more total protein, total fat, and ash than traditional meats i.e. chicken, pork, beef, fish, and eggs. However, the authors cited the chemical content of insect body depends on species, climate, habitation, and feed.
Tenebrio molitor larvae and crickets showed a high GE content of 7,188.6 kcal/kg and 5,942.6 $\mathrm{kcal} / \mathrm{kg}$ respectively, when compared to other feedstuffs, such as grain corn with an average of GE of 4,432.95 kcal/kg (Rostagno et al., 2017). The contents of NDF and ADF found in larvae of mealworm (Tenebrio molitor L.) were $71.8 \mathrm{~g} / \mathrm{kg}$ and $64.0 \mathrm{~g} / \mathrm{kg}$, respectively. The NDF observed in crickets of the genus Gryllus assimilis was $277.8 \mathrm{~g} / \mathrm{kg}$ and the ADF was $193.0 \mathrm{~g} / \mathrm{kg}$. Finke (2007) stated differences between NDF and ADF are generally associated with hemicellulose content, but in insects, these analyses may be associated with chitin content. The author reported the ADF may contain up to $68.8 \%$ of the total amino acids present in insects, resulting in high levels of NDF and ADF in the samples. Chitin is a structural polysaccharide composed of $\beta-(1-4)$ bonds linking $\mathrm{N}$-acetylglucosamine residues which acts improving immune responses (Muzzarelli, 2010). Veldkamp et al. (2012) stated the usage of insects in the diet of birds would have immunological effects due to chitin. 
The determined amounts of Ash, P, K, Na, Ca, $\mathrm{mg}, \mathrm{Fe}, \mathrm{Mn}, \mathrm{Zn}$, and $\mathrm{Cu}$ in the Tenebrio molitor L. were $36.8 \mathrm{~g} / \mathrm{kg}, 8.56 \mathrm{~g} / \mathrm{kg}, 8.39 \mathrm{~g} / \mathrm{kg}, 1.39$ $\mathrm{g} / \mathrm{kg}, 0.44 \mathrm{~g} / \mathrm{kg}, 2.3 \mathrm{~g} / \mathrm{kg}, 48.4 \mathrm{mg} / \mathrm{kg}, 15 \mathrm{mg} / \mathrm{kg}$, $189 \mathrm{mg} / \mathrm{kg}$, and $18 \mathrm{mg} / \mathrm{kg}$ of feed, respectively. In the crickets, the quantified contents were 49.1 $\mathrm{g} / \mathrm{kg}$ (Ash), $8.30 \mathrm{~g} / \mathrm{kg}(\mathrm{P}), 11.6 \mathrm{~g} / \mathrm{kg}(\mathrm{K}), 1.10$ $\mathrm{g} / \mathrm{kg}(\mathrm{Na}), 3.88 \mathrm{~g} / \mathrm{kg}(\mathrm{Ca}), 0.82 \mathrm{~g} / \mathrm{kg}(\mathrm{Mg}), 96.8$ $\mathrm{mg} / \mathrm{kg}(\mathrm{Fe}), 23.7 \mathrm{mg} / \mathrm{kg}(\mathrm{Mn}), 18.3 \mathrm{mg} / \mathrm{kg}(\mathrm{Zn})$ and $21.7 \mathrm{mg} / \mathrm{kg}(\mathrm{Cu})$. Siemianowska et al. (2013) stated that fresh and powdered larvae of mealworm are characterized by high content of minerals containing more phosphorus, magnesium, zinc, iron, cupper, and manganese than Polish conventional meats of animals and eggs. Larvae of mealworm (Tenebrio molitor L.) and crickets of the genus Gryllus assimilis may be alternatives for reducing the use of vegetable protein sources in animal feed.

Keywords: poultry farming, insects, protein

\section{RESUMO}

Atualmente, tem-se discutido a utilização de insetos na alimentação animal devido ao seu potencial para substituir as fontes tradicionais de proteína utilizadas. O objetivo deste trabalho foi determinar a composição nutricional de larvas de Tenebrio molitor e de grilos do gênero Gryllus assimilis. Os teores de energia bruta ( $\mathrm{kcal} / \mathrm{kg})$, proteína bruta $(\mathrm{g} / \mathrm{kg})$, extrato etéreo $(\mathrm{g} / \mathrm{kg})$, cinza $(\mathrm{g} / \mathrm{kg}), \mathrm{FDN}(\mathrm{g} / \mathrm{kg})$ e FDA $(\mathrm{g} / \mathrm{kg})$ encontrados nas larvas de Tenebrio molitor foram de 7.188,6, 490,2, 335,4, 36,8, 71,8, e 64,0 respectivamente; nos grilos (Gryllus assimilis), os valores foram de 5.942,6, 541,3, 75,2, 49,1, 277,8, e 193,0 respectivamente. Os macros e microminerais quantificados foram fósforo, potássio, sódio, cálcio, magnésio, ferro, manganês, zinco e cobre. Nas larvas de Tenebrio molitor, os valores encontrados foram de $8,56 \mathrm{~g} / \mathrm{kg}, 8,39 \mathrm{~g} / \mathrm{kg}, 1,39 \mathrm{~g} / \mathrm{kg}, 0,44 \mathrm{~g} / \mathrm{kg}, 2,3 \mathrm{~g} / \mathrm{kg}, 48,4 \mathrm{mg} / \mathrm{kg}, 15 \mathrm{mg} / \mathrm{kg}, 189 \mathrm{mg} / \mathrm{kg}$ e $18 \mathrm{mg} / \mathrm{kg}$ respectivamente. Para os grilos (Gryllus assimilis), os teores encontrados foram respectivamente de 8,30 $\mathrm{g} / \mathrm{kg}, 11,6 \mathrm{~g} / \mathrm{kg}, 1,10 \mathrm{~g} / \mathrm{kg}, 3,88 \mathrm{~g} / \mathrm{kg}, 0,82 \mathrm{~g} / \mathrm{kg}, 96,8 \mathrm{mg} / \mathrm{kg}, 23,7 \mathrm{mg} / \mathrm{kg}, 18,3 \mathrm{mg} / \mathrm{kg}$ e 21,7 mg/kg. Larvas de Tenebrio molitor $e$ grilos do gênero Gryllus assimilis podem ser alternativas para reduzir o uso de fontes de proteína vegetal na alimentação animal.

Palavras-chave: avicultura, insetos, proteína

\section{ACKNOWLEDGEMENTS}

The authors express their gratitude to the Department of Animal Science of the Federal University of Sergipe, Fundação de Apoio à Pesquisa e à Inovação Tecnológica do Estado de Sergipe - FAPITEC/SE and COPES - UFS.

\section{REFERENCES}

BARROSO, F.G.; HARO, C.; SÁNCHEZMUROS, M. et al. The potential of various insect species for use as food for fish. Aquaculture, v.422-423, p.193-201, 2014.

BELFORTI, M.; GAI, F.; LUSSIANA, C. et al. Tenebrio Molitor meal in rainbow trout (Oncorhynchus Mykiss) diets: effects on animal performance, nutrient digestibility, and chemical composition of fillets. Ital. J. Anim. Sci., v.14, p.670-676, 2015.
COSTA, S.M. Proteínas de larvas de Tenebrio molitor (l., 1758): extração, caracterização e aplicação num produto alimentar. 2017. 93f. Dissertação (Mestrado em Segurança Alimentar) - Faculdade de Medicina Veterinária, Universidade de Lisboa, Lisboa, PT.

DE MARCO, M.; MARTÍNEZ, S.; HERNANDEZ, F. et al. Nutritional value of two insect larval meals (Tenebrio molitor and Hermetia illucens) for broiler chickens: Apparent nutrient digestibility, apparent ileal amino acid digestibility and apparent metabolizable energy. Anim. Feed Sci. Technol., v.209, p.211-218, 2015.

FINKE, M.D. Estimate of chitin in raw whole insects. Zoo Biol. v.26, p.105-115, 2007.

FISKE, C.H.; SUBBAROW, Y. The colorimetric determination of phosphorus. J. Biol. Chem. v.66, p.375-400, 1925. 
FONTES, T.V.; OLIVEIRA, K.R.B.; ALMEIDA, I.L.G. et al. Digestibility of insect meals for Nile tilapia fingerlings. Animals, v.9, p.1-8, 2019.

MUZZARELLI, R.A.A. Chitins and chitosans as immunoadjuvants and non-allergenic drug carriers. Mar. Drugs, v.8, p.292-312, 2010.

OFFICIAL methods of analysis of AOAC International. 15.ed. Gaithersburg: Association of Official Analytical Chemists, 1990. 1200p.

RAVZANAADII, N.; KIM, S.; CHOI, W.H. et al. Nutritional value of mealworm, Tenebrio molitor as Food Source. Int. J. Ind. Entomol. v.25, p.93-98, 2012.
ROSTAGNO, S.H.; ALBINO, L.F.T.; HANNAS, M.I. et al. Tabelas brasileiras para aves e suínos: composição de alimentação e exigências nutricionais. 4.ed. Viçosa, 2017. $488 \mathrm{p}$.

SIEMIANOWSKA, E.; KOSEWSKA, A.; ALJEWICZ, M. et al. Larvae of mealworm (Tenebrio molitor L.) as European novel food. Agric. Sci., v.4, p.287-291, 2013.

VELDKAMP, T.; VAN DUINKERKEN, G.; VAN HUIS, A. et al. Insects as a sustainable feed ingredient in pig and poultry diets - a feasibility study. Wageningen: Livestock Research, 2012. 48p. 